\author{
Schmidt M., Sagynbekova L. (2008):'Migration past and present: changing \\ patterns in Kyrgyzstan'. In: Central Asian Survey,27:2,111 - 127. DOI: \\ 10.1080/02634930802355030.
}

\title{
Migration past and present: changing patterns in Kyrgyzstan
}

\author{
Matthias Schmidt and Lira Sagynbekova
}

Internal and international labour migration is a main livelihood strategy for many people in rural areas of Kyrgyzstan. It is estimated that approximately one-third of the employable population of Kyrgyzstan is working abroad. However, current labour migration phenomena are not exceptional since Central Asia's history has always been characterized by the movement of people, including external and internal, forced and voluntary, legal and illegal, permanent and temporary, ethnically or economically motivated migration. This article gives an overview of the historical and present migration processes with a special focus on three village communities in rural Kyrgyzstan. It deals with the opportunities and difficulties with which labour migrants and their nonmigrating family members are confronted today. The results are based on extensive field work in Kyrgyzstan.

\section{Keywords: migration history; labour migration; Kyrgyzstan}

\section{Introduction}

In the Central Asian state of Kyrgyzstan, spatial mobility is a prevalent characteristic. For centuries, the area along the Silk Road has served as a transit corridor for goods, people and ideas; furthermore, spatial mobility was necessary to sustain livelihoods in such a semi-arid region. Pastoral nomads utilized the mountain steppes of the Tian Shan and Pamir mountains by moving with their yurts and stocks from one place to the other. Russian expansion in the nineteenth century was associated with high migration rates of Russian peasants establishing the Central Asian regions as colonies of the Tsarist Empire. A further increase in migration rates from the centre to the peripheries accompanied the Soviet modernization programmes that followed. Under Stalin's rule, various national groups were deported from the European parts of the Soviet Union to Central Asia for political reasons. After independence in 1991, a large wave of reverse migration of the once voluntary or forced migrants has shaken Central Asia (Islamov 2000, Korobkov 2007). Today, migration from the Central Asian peripheries to the former centre of the Soviet Union, mainly for economic reasons, dominates the current migration patterns. Recent internal and external labour migration in Kyrgyzstan is influenced by economic considerations, particularly unemployment, low earnings, poverty and deteriorating living conditions.

Elebaeva (2002) estimated that more than 1.3 million people (one-quarter of the total population of Kyrgyzstan) moved at least once in search of work inside the country or left it. In general, intense population movements from rural to urban, from south to north or from east to west are characteristic of the whole post-Soviet space and are the focus of several studies. Schwarz (2000) and Stadelbauer (2003) deal with migrations in the Commonwealth of Independent States (CIS) from a geographical standpoint by using mainly quantitative data and trying to classify the post-Soviet migration patterns. Internal and external migration in post-Soviet Russia, Uzbekistan and Kazakhstan is analysed by papers written mainly from a political science or economics viewpoint and often by using official data (Wegren and Drury 2001, Becker et al. 2005, Yessenova 2005, Radnitz 2006). This holds true for the studies by Abazov $(1999,2000)$ on migration in Kyrgyzstan that are mainly based on assumptions and rough estimates, while only a couple of papers on internal and external labour migration in Kyrgyzstan are based on their authors' own surveys (Elebaeva 2004, Bichsel et al. 2005, Ergeshbaev 2006).

The aim of this article is to fill the gap in the existing literature by exploring recent migration patterns against the background of past population movements. This is because migrations are not only situated in individual or collective decisions and the actions of interpersonal migration networks, but also have to be analysed in the context of socio-economic structures and patterns such as the shared history of the Soviet Union. In particular, the article intends to analyse continuity and change in migration patterns, types and means of recent labour migration phenomena, opportunities and difficulties with which migrants and their non-migrating family members are confronted, and finally the consequences of these movements. To explore present labour migration phenomena a survey was conducted in rural Jalalabad oblast. Today, $64.6 \%$ of Kyrgyzstan's population 
live in rural areas where the economic difficulties connected with the transformation process are particularly formidable (National Statistical Committee of the Kyrgyz Republic 2004, p. 41). The article first sets patterns of population movement in Kyrgyzstan in historical perspective, and then aims to expand our understanding of recent migration processes in Kyrgyzstan that are the living reality of millions of people in Central Asia, thus providing a basis for comparison with other post-Soviet Central Asian states.

\section{History of migration in Kyrgyzstan Russian immigration and colonization}

Mobility has been an enduring feature of the Kyrgyz population: over the course of time, Kyrgyz nomads of the Tian Shan Mountains changed their locations regularly in search of suitable pastures for their animals. Usually the nomad families lived together in clans, 1 settled during the winter in less snowy valleys and moved in summer to pastures at higher locations, known as jailoos. The end of the nomadic life-style started with the conquest of the area by Russian troops and its incorporation into the Tsarist Empire in 1876.

Colonization of the newly incorporated parts of the Russian empire was connected with migrations from its centre to the peripheries. After 1890 many Russian peasants, liberated by their emancipation in 1861, migrated to Central Asia. It was part of the Russian military strategy to strengthen the Russian population in the peripheries of the Tsarist Empire (Katsunori 2000). This trend was further encouraged by Stolypin's Resettlement Act of 6th June 1904 that came into force in Central Asia in 1907, granting the migrants privileges such as full exemption from taxation and all compulsory service for five years, various subsidies to farming and building materials (Katsunori 2000, p. 71). This resulted in a massive migration of Russian peasants, for whom land was expropriated from the native Kyrgyz. The relation between Russian peasants and the Kyrgyz nomads began to worsen and culminated in a violent uprising of the Kyrgyz after the Tsar's decree recruiting indigenous people from Central Asia for military service in 1916. After the Tsarist troops had bloodily defeated the revolts, thousands of Kyrgyz took refuge in Xinjiang. These processes of Russian immigration and Kyrgyz refugee flows changed the composition of the population significantly between 1916 and 1920. The number of Russians (including Ukrainians and other Europeans) almost doubled, while the Kyrgyz population was reduced by half (Katsunori 2000, p. 82).

\section{Forced and regulated migration during the Soviet era}

After the establishment of the Soviet Union, the immigration of Russians and other Europeans to Central Asia continued, but was supplemented by other forms of population movement which were initiated and forced by the Soviet government.

First, the Soviet rulers declared nomadic pastoralism to be a life-style that was no longer viable and had to be eliminated. They justified the settlement of nomadic groups in ideological terms to enable the establishment of modern institutions, the building of schools to expand literacy and participation in the modern economy and state institutions (Schoeberlein 2000). Moreover, settlement certainly facilitated political control of the people. The settlement of nomads radically changed their social organization and often resulted in severe poverty among them since they were unaccustomed to agriculture.

Second, during Stalin's collectivization and political 'purges' a broad segment of the pre- Revolutionary elite and religious classes was forcibly translocated. Thousands of so-called kulaks were deported during the collectivization in the 1930s to prison-like gulags in Siberia. Kulaks were by definition rich people or classenemies, but in actual fact they might have had no more than a couple of animals. Being designated as a kulak more often 'reflected one's unwillingness to hand one's property over to the collective farm' (Schoeberlein 2000, p. 54).

Third, thousands of Germans (descendants of the eighteenth-century German migrants to the Volga region), Chechens, Crimean Tatars, Turkish-Meshetinians, Karachais, Koreans and others were deported to Central Asia and Siberia during World War II. For example, more than 70,000 Chechens were deported to the Kyrgyz SSR in 1944 alone (Polian 2004, p. 148).

Fourth, during WorldWar II and the post-war restoration of the Soviet economy a considerable number of mainly military industrial plants along with their workforce (mostly Russians and Ukrainians) were relocated to Central Asia from the European part of the USSR, where their functioning was threatened by military action and postwar turbulence. The inflow of people during these years increased the multi-ethnic character of the area and resulted in significant population growth, especially in the cities. A huge inflow of Russians into Central Asia characterized the period between 1926 and 1959; their number in Kyrgyzstan increased during this time from 116,810 to 623,500 . As a consequence, the share of the titular population decreased from $66.7 \%$ (1926) to $40.5 \%$ (1959) although the total number of Kyrgyz increased (Akademiia Nauk Kirgizskoi SSR 1982, p. 100) (Figure 1). In the 1960s and 1970s Moscow allocated large investments into the republic's hydroelectric power sector, mining and metallurgical plants for which engineers and other experts were moving to Kyrgyzstan. The 
industrialization of Kyrgyzstan relied almost entirely on immigrant labour (mainly ethnic Russians) into the republic. However, during the de-Stalinization campaigns some of the deported people began to leave the Kyrgyz SSR and returned to the places of their origin; for example, most of the Chechens went back to Chechnya during the 1960s.

The centrifugal migration in the Soviet Union continued until the early 1970s. Then the migration flow turned towards the centre. During the 1970s and 1980s, the inflow into Central Asia from Russia declined, so that the number of emigrants slightly exceeded the number of immigrants in the Kyrgyz SSR (National Statistical Committee of the Kyrgyz Republic 2002, p. 159). This process was stimulated by the agrarian over-population, hard competition in the labour markets and the growing strata of qualified personnel among the native population in Central Asia, which caused the non-titular population to leave these regions (Zayonchkovskaja and Polian 1998, p. 161). Starting in the mid-1980s under the Gorbachov administration, ethnically motivated migration increased, following the liberalization of emigration rules and as a consequence of inter-ethnic and other conflicts (Islamov 2000, p. 183). In particular, Germans, Jews and Greeks tried to migrate to their historical motherlands outside the Soviet Union, and Russians, Ukrainians, Meskhetian Turks and Crimean Tatars within the USSR.

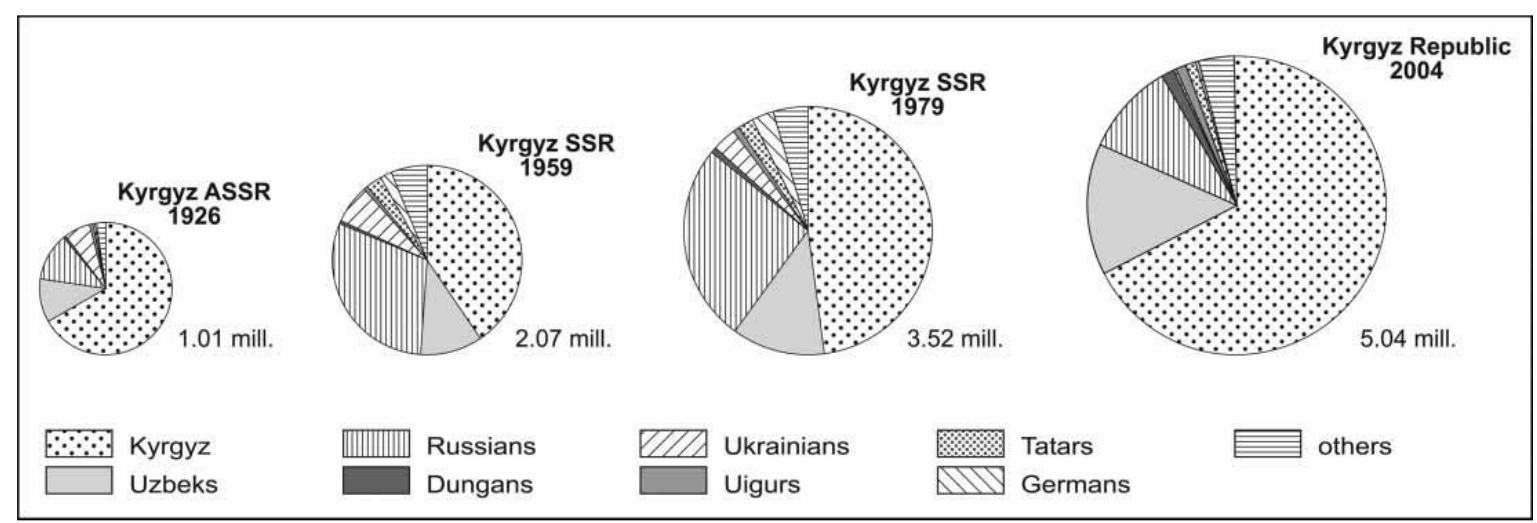

Figure 1. Ethnic structure of Kyrgyzstan. Sources: Akademija Nauk Kirgisskoj SSR (1982); National Statistical Committee of the Kyrgyz Republic (2000, 2004).

Internal migration for material reasons and relocation of labour forces did exist in the Soviet Union as well, but to a much smaller extent. Some parts of the rural population simply wanted to escape the poor living conditions in the countryside. The central authorities tried to prevent this escape by restrictions on mobility, by means of internal passports that were not delivered in some regions until the 1980s (Titma and Tuma 1992, p. 33), residence permits were needed in certain locations, places on means of transport had to be obtained (Pole and Filatotchev 1992, p. 433), or by the unconstitutional use of the propiska (registration) system that was introduced in 1932 (Matthews 1993, p. 27, Wegren and Drury 2001, p. 17). However, due to the fact that higher wages were offered in regions with harsher living conditions to attract labour, migration during the Soviet era was also influenced by the workers' self-interest and thus included market-type elements (Sutherland and Hanson 2000, p. 82).

With regard to rural-urban migration in the USSR, out-migration from rural areas was highest in the post-war period and in the early 1970s (Zaslavskaya and Korel 1984). The governmental policy aimed to improve the economic situation and living conditions in the rural areas in order to reduce the loss of rural population through migration. This resulted in a comparable standard of living in the villages and the cities. According to Rowland (1988, p. 822) the real incomes were actually higher in the countryside due to income from private plots and lower costs of living.2 Permission for individuals to own small plots of land enabled the peasants to harvest agricultural produce and sell it in the kolkhoz markets. This type of parallel economy provided sizeable additional earnings for people in rural areas. Consequently, after a steady increase over the decades, the proportion of the urban population in the Kyrgyz SSR remained stable at approximately 38\% in the 1980s (National Statistical Committee of the Kyrgyz Republic 2000).

It is worth mentioning that the mobility of the Kyrgyz population in the 1970s and 1980s was much lower than that of Russians (Rybakovskiy and Tarasova 1991, p. 465). Besides the general drawbacks of urban life such as limited housing capacity, difficulties of obtaining satisfactory employment and the need for good knowledge of the Russian language, young natives were hampered in making important decisions as to choice of profession, place of residence or place of work by their greater dependency on their parents (Rybakovskiy and Tarasova 1991, p. 469), and they were socially and economically more strongly bound to their extended families. Although 
the number of Kyrgyz living in Russia multiplied 2.8 times in the 1970s and 1980s Kumskov 2000), only 42,000 Kyrgyz resided in Russia in 1989 (Pole and Filatotchev 1992, p. 445).

In general, the Soviet administration planned, restricted and strictly controlled population movements as part of its planned economy and modernization policy. The Soviet leaders often used forcible relocation of certain categories of the population as an instrument in achieving security, ideological and economic goals, such as solving the labour shortage in some parts of the USSR and transforming the organization of communities. Results of a National Socio-demographic poll in 1985 showed that $41 \%$ of the inhabitants of the Kyrgyz SSR had changed their place of residence at least once in the course of their lives (Rowland 1988, p. 819). Meanwhile, external migrations across the 'Iron Curtain' were rare.

\section{Repatriation or ethnic transfer in post-Soviet Kyrgyzstan?}

Since the collapse of the Soviet Union in 1991, there has been a significant increase in migration rates. Political and ethnic conflicts, the lack of guarantees concerning basic civil rights for individuals who suddenly found themselves 'abroad', growing unemployment, a sharp decline in living standards, and the aspirations of members of ethnic groups having been violently removed from their historical territories resulted in enormous numbers of refugees, forced and voluntary migrants. The main migratory trend on the territory of the former USSR was a population flow from the peripheries to the centre, the Russian Federation (Borovik and Chemberko 1998, Zayonchkovskaja and Polian 1998, p. 169).

Accordingly, the migration flow out of the Kyrgyz Republic intensified shortly after 1991 (Figure 2). It reached its highest level in 1993 when more than 140,000 people left the country. Since then, the emigration rates have fallen below the level of the Soviet era with a slight increase again during the last few years. Eighty-four per cent of all emigrants moved to CIS countries, mainly to Russia followed by Uzbekistan, Kazakhstan and Ukraine, persons

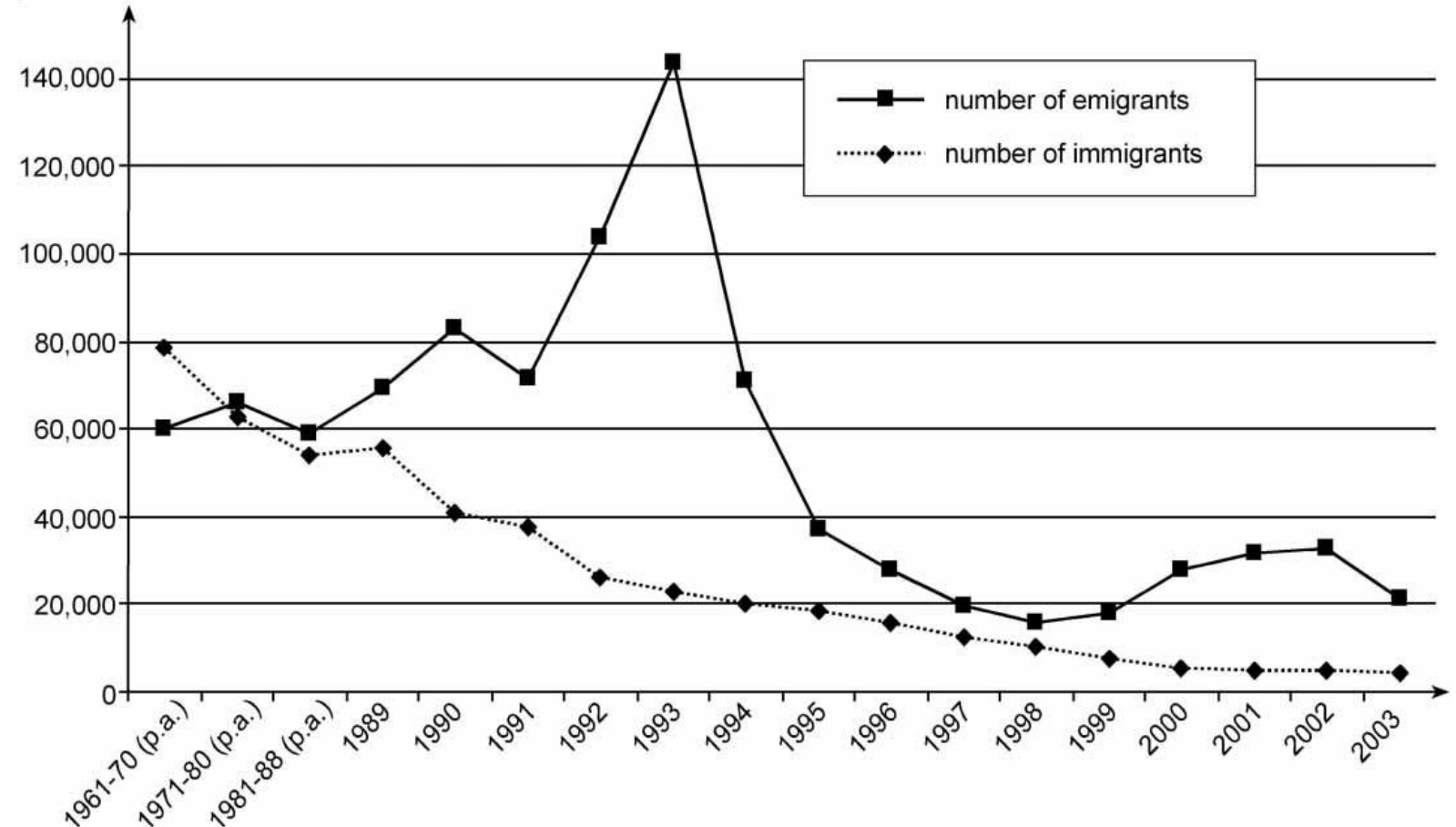

Figure 2. Migration to and from Kyrgyzstan. Sources: United Nations in the Kyrgyz Republic (2001, 2003); National Statistical Committee of the Kyrgyz Republic (2004).

approximately $13 \%$ to Germany, and $3 \%$ to other countries. The official number of 688,000 emigrants revealed that almost one in six inhabitants left the Kyrgyz Republic between 1989 and 1999 (National Statistical Committee of the Kyrgyz Republic 2002, p. 162).

Since many of the emigrants are highly qualified workers from urban areas, this 'brain drain' has led to a shortage of qualified human capital and worsened the hardships of the transition period; substantial efforts and finances are required to train new specialists. At the end of the Soviet era, Russians were overrepresented in industry, communication, construction and government (with approximately $40 \%$ of the workforce), but underrepresented in agriculture (6.8\%) (Kaiser 1995, p. 95).

The emigration of Russians and Europeans might be interpreted as repatriation or as ethnic transfers. However, economic factors such as high unemployment and the decline in living standards were probably the most important driving forces for this large outflow from Kyrgyzstan. In addition, many Russians felt increasing job 
competition from local nationalities in their work places and had experienced difficulties at work (Ginzburg et al. 1993, p. 38). As a result of the massive emigration of the Russian and European population, in 2004 the share of the titular population, ethnic Kyrgyz, had increased to $67.4 \%$ of Kyrgyzstan's total population of 5,065,000, while the proportion of ethnic Russians dropped to $10.3 \%$ and the number of Ukrainians and Tatars had dropped by half (National Statistical Committee of the Kyrgyz Republic 2004, p. 43-44). The Uzbek community became the largest minority in Kyrgyzstan with a share of $14.2 \%$. Apart from migration processes, the higher natural population growth among Kyrgyz and Uzbeks is also responsible for this trend. Since 1989, the numbers of Kyrgyz had grown by 1.1 million and the number of Uzbeks by more than 150,000 (National Statistical Committee of the Kyrgyz Republic 2000, 2004).

However, the already mentioned large labour surplus and the recent economic difficulties have prepared the ground for large-scale movements of people of working age in search of jobs and better living conditions. Already during the Soviet era, the so-called 'Central Asian Problem' - namely the increasing population pressure among the indigenous populations in the rural areas of Central Asia and thus the labour surpluses - had become a topic of interest both for scientists and politicians (Rybakovskiy and Tarasova 1991, p. 466). The arguments basically centred on the question of 'whether or not a sufficient amount of investment and jobs will be placed in Central Asia to accommodate a rapidly growing indigenous work force and thus whether or not their out-migration to other regions of the USSR will occur' (Rowland 1988, p. 821).

\section{Labour migration as a livelihood strategy in rural Kyrgyzstan}

The Soviet modernization policy promoted the creation of a diversified economy and an advanced educational, health and welfare system that reached the rural areas of Central Asia as well. The central planning system of the Soviet Union reduced regional disparities in development through the system of centralized budget transfers by channelling investment funds, equipment, technology and expertise from relatively well-developed to less developed regions (Pole and Filatotchev 1992, p. 445). However, in 1991 there still existed a significant gap between the levels of development of different regions, particularly between the European part of the USSR and Central Asia. The disintegration of the all-Union system and the shift from the socialist economic system to a market economy led to a sharp economic decline and the destabilization of millions of livelihoods in Central Asia. In rural Kyrgyzstan, the closure or restructuring of the main employers, state and collective farms (Bloch and Rasmussen 1998), influenced the life chances of the population dramatically. Without employment alternatives many people started searching for jobs in urban areas or abroad. The Representatives of Kyrgyz State Committee in Moscow in 2006 officially registered 153,886 Kyrgyz citizens in the Russian Federation, of whom 32,536 possessed official work permits. 3 According to other estimates, more than half a million persons from Kyrgyzstan live and work in Russia (Toralieva 2006), which in total accounts for approximately one-third of the economically active population of Kyrgyzstan (Sarygulov 2005). The differences between official numbers and estimates demonstrate that the labour migration processes often follow unofficial and even illegal paths. After arriving in Russia many Kyrgyz citizens obtain short-term or fake registrations, and many do not bother to register at all.4 Similarly, the scale of internal labour migration, mainly directed from rural areas towards the capital Bishkek, is difficult to determine since most internal migrants do not register at their destination (International Organization of Migration 2001).

\section{Case study and methods used}

To investigate recent labour migration processes in rural Kyrgyzstan, data were collected in various governmental offices at local, regional and national levels. However, it must be emphasized that official information does not reflect the living reality of the rural population, neither in the past nor today. During the Soviet period, statistical information had to be in line with ideological and political aims, so that the numbers given tended to be politically motivated estimates. Current data also have to be used with care because temporary migration happens in most cases without official registration. However, the present migration phenomena are very difficult to understand only through official figures and 'outsider perspectives'. Thus, the analysis is based on case study research with data gathered using diverse methods such as participant observation, questionnaires and interviews.

A questionnaire survey was carried out between 2005 and 2007 with a total of 500 households and approximately a dozen focused interviews with selected key-informants in the villages of Arslanbob, Kyzyl Unkur and Karalma in Jalalabad oblast of Kyrgyzstan, where the economic situation is more severe than in the north of the country. The longitudinal perspective made it possible to follow the fortunes, successes and failures of different migrants. In addition, from October 2007 to January 2008 questionnaires were administered in Moscow to 100 labour migrants from Kyrgyzstan, 55\% of which came from Jalalabad oblast. Households and migrants were randomly selected. 5 The qualitative interviews, which took up to three hours, were intended to gain more detailed information on specific cases, for a hermeneutic understanding of the migration process. 
The three communities (ailo"kmo"tu") of Arslanbob, Kyzyl Unkur and Karalma are situated in the Jalalabad region of Kyrgyzstan, in an area characterized by high mountains and relics of naturally occurring walnut forests. Approximately 16,500 people, mainly Uzbeks (78\%), live in Arslanbob, the central village of which has a settlement history of several hundred years. The villages of Kyzyl Unkur and Karalma were founded at the beginning of the twentieth century and are today populated by 4170 and 3160 people, respectively, almost all of them of Kyrgyz ethnic origin.6 However, until the second half of the twentieth century a high number of Russians, Tatars, Ukrainians and Germans also settled in these villages. A major part of the Russian speaking population left the villages and already moved to nearby towns in the 1970s, mainly because of the lack of Russian-language education facilities in the rural areas. During the 1990s most of the remaining Russians, Ukrainians, Tatars and Germans left the villages and migrated to their countries of origin. Today, the average household size in these villages is 5.2 persons; approximately $40 \%$ of the population are below working age, while only $6 \%$ are above working age.7 During Soviet times, the majority of the population in all three villages was employed by the local state forest enterprises (leshoze) in forestry, wood processing and bee keeping as well as in agricultural activities. Jobs and wages were guaranteed by the state. The management of the state forest enterprises was dominated by ethnic Russians. Kyrgyz and Uzbeks worked as labourers, forest assistants or in the wood-processing units. Only from the 1970s onwards did non-Russians reach higher positions such as forest engineers, clerks or even directors. Apart from the leshozes, schools, the local administration and several holiday camps offered employment.

\section{Economic problems in rural areas of Jalalabad region}

The collapse of the Soviet Union has unsettled the livelihoods of the local population and the villages under study underwent an economic decline. In contrast to Kyrgyzstan's sovkhozes and kolkhozes the state forest farms are still running, but they have reduced their workforce dramatically. Today, a minority of the population has formal employment at the leshozes, the village administrations, the local schools or kindergartens, and at medical centres. Some people have started small businesses as merchants, drivers or are temporarily earning money in tourism. Almost all households carry out agricultural and forestry activities partly for subsistence, and partly to earn an income. All forest and arable land is still owned by the state, while the households have usufruct rights on specific plots of land. Most households keep a small garden for vegetables and potatoes for their own consumption, a small arable field of not more than 0.3 ha cultivated with sunflowers, potatoes or maize, and have access to forest plots of approximately 1 ha where they collect walnuts, apples and herbs, and hay for their livestock (Schmidt 2005). Their livestock - approximately one to three cows and a couple of sheep per household - is driven to high pastures (jailoo) in summer and herded in the forest area in early autumn. Nuts, apples and milk products are sold on the market, and animals are seen as important capital that can be sold in case of emergencies. However, the limited fields, herds and forest resources are not sufficient to sustain the livelihood of the households, so other income sources are necessary. Thus the official unemployment rate of approximately $10 \%$ does not represent the real employment situation accurately since most people are not registered as unemployed but as farmers or dependent household members. The fact that in 2007 almost half of the population in these villages lived below the poverty line, with a monthly income of less than US\$15,8 gives a more realistic picture of the pressing economic hardships.

Due to the very limited employment opportunities accompanied by a high population growth, many people of working age need to look for other ways to generate an income. Today, a high number of local inhabitants are dependent on remittances from migrant family members. Internal and external labour migration has become a typical feature of the villages that were surveyed.

\section{Reasons for migration}

Poverty and insecure livelihoods combined with a lack of opportunities to improve personal economic situations in the villages are the main driving forces behind migration. Among the labour migrants interviewed the motivation to support their families is most important, followed by the wish to earn money in order to make major investments, such as building a house or starting a small business, paying for education, medical treatment or lifecycle events such as weddings and funerals. The economic arguments for migration are based on the lack of employment opportunities in the village combined with insufficient income from agriculture on the one hand, and the hope of finding employment abroad with which they can improve their material situation on the other hand. Other push factors are the worsening of living conditions in the villages, debts due to a bad harvest, alcohol or other problems, or insufficient educational facilities, while political reasons play an insignificant role.

According to the survey in Moscow, $62 \%$ of the interviewed migrants moved to improve their own material status and to earn more money than at home; unemployment and debts are other push factors (see Table 1).

It seems obvious that decisions to migrate are mainly governed by economic considerations with the aim of securing livelihoods or minimizing risks, and they represent a rational choice after cost-benefit analyses have 
been made.9 However, focusing only on prerequisites, forms and consequences of migration as a one-off and uni-directional translocation transforms regions of origin and regions of destination into 'containers' of territorial and social spaces. But in reality present migrations are rarely unidirectional, and social networks, namely the presence and even more the success of relatives and acquaintances in the place of destination, play a major role in the decision to migrate and the form of migration. Migrants move in the frame of complex networks and often follow cycles (Boyd 1989, Fawcett 1989, Wilpert 1992).

\section{Destination, duration of stay and occupation of labour migrants}

Approximately one-third of all labour migrations from the surveyed villages are internal, mainly to the capital Bishkek, but also to the regional centre Jalalabad or to Osh, the second largest city of Kyrgyzstan. Among the external migrants, four-fifths are moving to Russia, most of the others to Uzbekistan and an insignificant number to Kazakhstan or other countries. The main destinations for people from the villages studied are the Russian cities of Moscow, Magnitogorsk, Sverdlovsk, Krasnojarsk, Irkutsk, Cheljabinsk and St Petersburg. Russia attracts workers because of its extensive labour market, its relatively stable political situation and rapid economic growth. As outlined previously, the direction of the migrants is largely connected with the presence of relatives or acquaintances in these cities that function as the first destination. Networks between the regions of origin and destination are important, since they make migration decisions more calculable, help to reduce costs and risks, and provide support for newly arrived migrants. Frequent movements between two or more places are the living reality of many 'transmigrants' or 'transnational migrants', resulting in an evolution of multi-local social spheres which are situated in and between regions (Glick Schiller et al. 1992, Bailey 2001, Pries 2001). Reports of successful migrants create new pull factors for further migrations, which can be seen by the fact that at present more than 40 people from the village of Arslanbob live and work in the Russian city of Sverdlovsk. The trigger of this connection was a marriage between an Uzbek man from Arslanbob and a Russian woman from Sverdlovsk, where the young man did his military service in 1960. After marriage the couple settled in Arslanbob. One of their sons moved to Sverdlovsk in the 1990s in search of work. Being successful, he called his friends to follow him and established a network for others from Arslanbob who were willing to migrate.

Table 1: Reasons to migrate to Moscow

\begin{tabular}{lc}
\hline Reasons to migrate to Moscow & $\%$ \\
\hline Improvement of own material status & 46 \\
Low salary in Kyrgyzstan & 16 \\
Unemployment in Kyrgyzstan & 16 \\
Debts & 8 \\
Following the call of relatives or friends & 5 \\
Others & 9 \\
\hline
\end{tabular}

Source: Authors' own survey among labour migrants in Moscow 2007-2008; $\mathrm{N}=100$.

By entering the labour market in Russia, the labour migrants from Kyrgyzstan face the problem that their skills, knowledge and education, which were important in rural Kyrgyzstan, are only of limited use. Therefore, the range of employment possibilities is rather limited. Well-educated migrants carry out low-prestige jobs that they would not perform at home.10 From the surveys it was established that most of the labour migrants from Kyrgyzstan are occupied at their destination in trade, the building sector, catering, industry, or in low-paid jobs such as sweepers or loaders. A smaller number are employed in transport and communication, education, medical services or other branches (see Table 2).11

With regard to the duration of labour migration, the survey showed that $63 \%$ of all labour migrants move temporarily. Their duration of stay abroad ranges from several weeks to a couple of years. However, many labour migrants do not know how long they will stay abroad; this depends on their success at their destinations. Seasonal migration, which lasts for three to six months, is also prevalent for external and internal labour migrants. Many of them repeat their migration every year or every two years; they usually move to the same place again owing to existing relations and networks. The reason for a repeated migration lies in the fact that the returned migrants do not in most cases find an adequate job at 'home'. Such people work and live most of the time in the foreign country but are still socially and emotionally connected with their home villages, showing the typical characteristics of a transmigrant or transnational biography (Bailey 2001, Pries 2001). The length of stay of the labour migrants in Moscow is higher than that of the internal migrants (see Table 3). Some migrants try to obtain Russian citizenship to legalize their stay in Russia or to settle there permanently. But according to the survey, $73 \%$ of the migrants in Moscow intend to return to Kyrgyzstan, while only $15 \%$ want to stay permanently in Russia. 


\section{Remittances and consequences for household members}

The family support network, especially in the rural areas, has increased in importance with the erosion of state benefits. Families provide a kind of safety net in the face of unemployment, declining living standards and poverty. Most of the labour migrants have dependants back at home, but according to the authors' survey in the villages only approximately $56 \%$ of the labour migrants support their families back home with cash, money transfers or remittances in kind, such as clothes, consumer goods or food. the reasons why dependants do not receive remittances from their migrant kin are numerous: the migrants remain unemployed or do not earn enough money; illegal fees have to be paid to the militia or they become ill.

Table 2: Occupation of labour migrants in their destination region

\begin{tabular}{lcc}
\hline Type of occupation & $\begin{array}{c}\text { Occupation of labour migrants from Arslanbob, } \\
\text { Kyzyl Unkur and Karalma in Russia in } \%^{\mathbf{a}}\end{array}$ & $\begin{array}{c}\text { Occupation of Kyrgyz labour } \\
\text { migrants in Moscow in } \%^{\mathrm{b}}\end{array}$ \\
\hline Trade & 31 & 25 \\
Construction & 30 & 15 \\
Catering & 8 & 15 \\
Industry & 8 & 10 \\
Loader & 6 & 9 \\
Sweeper & 5 & 2 \\
Transport and & 7 & 17 \\
$\quad$ communication & 5 & 2 \\
Others & 5 & 2 \\
\hline
\end{tabular}

Sources: "Authors' own survey in the villages of Arslanbob, Kyzyl Unkur and Karalma 2005, 2007; N $=240$.

'Authors' own survey among labour migrants in Moscow 2007-2008; N=100.

Table 3: Length of stay of labour migrants from Kyrgyzstan in Moscow

\begin{tabular}{lc}
\hline Duration & Migrants in Moscow in $\%$ \\
\hline $3-6$ months & 2 \\
6 months -1 year & 12 \\
$1-2$ years & 31 \\
More than 2 years & 18 \\
Permanent & 12 \\
No response & 25 \\
\hline
\end{tabular}

Source: Authors' own survey among labour migrants in Moscow 2007-2008.

A few migrants even receive help in the form of products and cash from their families at home. Of the migrants interviewed in Moscow, 73\% stated that they support their families. The obvious discrepancy between these figures might be explained by the migrants' desire not to lose face in the interview situation.

There is also an inconsistency in the results of the survey in the villages and in Moscow with respect to the amount of money transferred from the migrants to their families. According to the survey in Kyrgyzstan, the annual financial assistance of internal labour migrants to their families varies from US\$10-100, while some external migrants support their families annually with up to US\$2000. Most of the households interviewed receive on average US\$100-300 two to five times a year from their family members abroad.12 In Moscow, the migrants claimed to send higher sums, US\$2500 on average and up to US\$6000 per year. The remittances are primarily used for food, clothes, medical expenses, education or lifecycle ceremonies. In some rare cases, former migrants started a small business or bought a car to work as drivers. Investment in the construction of a house or the education of a family member is more frequent and is also seen as productive spending. However, in most cases the money is spent on consumption either for consumer goods or just to feed the family. In rural Kyrgyzstan too, Bichsel et al. (2005, p. 38) observed no visible shift from consumption needs in the beginning to more longterm investments in later years, although many had planned to invest in a small business. This is mainly due to urgent expenditures or the fact that the money received is hardly sufficient to cover basic needs.

Apart from the above-mentioned economic impact, migration is also connected with social and psychological consequences; it is changing the family and gender-and-age structures. There are many personal concerns because family members are separated for a long time. After their departure the household has to cope with a lack of labour force; in particular women suffer when male family members are absent because they must carry the entire workload, care for their children and solve family problems on their own. Most of the labour migrants live abroad without their families, causing family relations to deteriorate. Some women are confronted with further difficulties when the migrant husband marries another woman while he is away and does not return home. Therefore, divorce is often a consequence of migration, resulting in social and economic marginalization of the remaining family members. 
The fact that many migrants are not employed in their field of specialization is also problematic. Well-educated and skilled persons such as doctors, teachers or clerks with a high social status in the village are prepared to undertake any work, the least prestigious and the hardest jobs in construction, in the markets or in factories, which have nothing to do with their qualifications, because of their financial needs. As a result, these people suffer because of the discrepancy between their qualifications and the actual work that they would not do at home. In the opposite case - when a rural citizen with low status in his village has been successful at the place of destination, building a new house or starting his own business - he improves his social status in the eyes of his fellow villagers. Migration often leads to a change in the internal stratification of a village community.

It is still difficult to establish whether labour migration weakens the sending communities when particularly the well-educated and skilled people are leaving, or whether the remittances lead to a capital inflow that could promote a positive development of the whole community. On a personal level, there are many instances of material and social improvement of households. In addition, migration can help to enhance labour skills and industrial experience, and to promote personal development through enhanced exposure and knowledge. However, at the community level, migration does not directly contribute to a positive development of the village. The out-migration of a qualified workforce at the peak working age leads to a 'brain drain' which can worsen the prospects for socio-economic development in the long term. There is already a lack of teachers and physicians in many areas of Kyrgyzstan (Toralieva 2006). Moreover, due to the absence of family members, many households are looking for labourers to carry out their agricultural work such as grass cutting, and thus offer income opportunities for others. But there is already a shortage of manpower because most young men are looking for jobs, are studying or work in urban areas or abroad. However, there are some other positive indirect effects such as easier transport due to new car-ownership, or migrants being able to give loans to others. The increase in property prices might also be an effect of the cash inflow. In other parts of Kyrgyzstan, property prices have already doubled over the past few years, which is attributed to remittances sent from migrants abroad who have invested in property (Sulaimanova 2005, p. 11).

\section{Disappointments of labour migration}

According to the survey in the villages, for approximately $40 \%$ of the interviewees the labour migration process did not meet their expectations and was perceived as a failure. Some migrants return to their home villages after a short period of time without achieving their aims, and sometimes they are even unable to pay back the money borrowed for the journey.13 Approximately one-fifth of the households interviewed contain returned labour migrants who cut short their stay abroad. The main reasons for their return are family problems, followed by difficulties in finding a job, harsh living conditions, illness or accidents, low wages or unscrupulous gobetweens or middlemen.

Many people returned because they had been defrauded by middlemen who took part of the money earned as commission. As a result, some migrants were not able to send money to their families or were even unable to pay their own costs of living. It turned out that in reality some people only work to pay back their debts to the intermediary. Since most of the migrants have no legal work permit, they have no chance of making official complaints. Some of the migrants have an illegal status only because of local circumstances when, for example, the employer wants to avoid paying taxes and social contributions for them. Due to their illegal status they always fear judicial consequences and often have to bribe the militia who check their documents. Since illegal migrants need employment that is not controlled by the state, employers benefit from this by hiring migrants without a contract, paying them much lower wages than Russians earn, or demanding hard unskilled work which nobody else wants to do.14 Without the chance to ask for basic rights, they are sometimes exposed to appalling working conditions. Some of the migrants cannot endure these difficult conditions, but many others bear the psychological burden as the price they have to pay to improve their material situation. A significant number of migrants become ill or have an accident, mainly at work. In most cases, they have no health insurance and do not get proper medical treatment because of the high costs. Bankruptcy and stress are also characteristic of migrants who are occupied in trade. Their documents are frequently checked by the local law-enforcement agencies, and they often have difficulties with the customs at the border. Xenophobic reactions by the Russian population against immigrants from southern regions - whom they call 'blacks' - are also increasing (Schwarz 2000, p. 311). Many migrants have serious psychological and social problems in adjusting to these specific conditions in a foreign country; some of them start drinking and commit criminal offences. The way back home is also stressful for many migrants when they pass through the territories of Russia and Kazakhstan, where they are at the mercy of law-enforcement agencies: customs officials, border guards and the militia all demand their share of payment. They find various reasons to demand penalties for incorrect documents, to confiscate luggage or passports. According to a poll (Elebaeva 2004, p. 84), racketeering in Russia seems to be a common phenomenon, as well as monthly payments to local criminal structures.15 


\section{Conclusion}

Spatial mobility and migration are deeply rooted in the realities of Kyrgyzstan and should not be seen only as a transitory phenomenon. Before and after the Soviet period, the migration of residents of Kyrgyzstan is first and foremost a livelihood strategy. But the highest permanent migration rates - although not of people of Kyrgyz origin - occurred under Soviet rule, mainly in the form of forced displacement of people because of ideological, political and economic reasons. As a result Kyrgyzstan emerged as a multi-ethnic country in which the native Kyrgyz became a minority in the middle of the twentieth century but were regaining their absolute majority some decades later.

Although by 1991 the Soviet modernization policy had successfully reduced regional disparities in development through the system of centralized budget transfers, there still existed a gap between the levels of development in different regions, particularly between the relatively welldeveloped regions in the European part of the USSR and the less developed regions of Central Asia, which became even wider after the disintegration of the all-Union system. Greater freedom of choice and economic decline have led to ethnically and economically motivated migration patterns, since national identities are no longer treated as irrelevant legacies of pre-Soviet times and market forces have begun to influence the location of economic activities. The major trends are, first, a return migration of Russians and formerly displaced people and, second, the temporary or permanent labour migration of Central Asians, mainly to the former centre, Russia, where standards of living and the demand for labour are higher.

The evaluation here of recent phenomena has clearly shown that labour migration is both an opportunity and a threat. On the one hand, labour out-migration sometimes presents the only option for people to sustain their own livelihood or that of dependent households. This is particularly important in view of the present desperate economic realities in rural Kyrgyzstan, with high unemployment rates and mass poverty. Following the arguments of Seddon (2004, p. 415), remittances from migrants might help to improve living standards, alleviate poverty and create markets and employment. In rural Kyrgyzstan, the construction of new houses and the appearance of many consumer goods are obvious evidence of the transfer of foreign currency, but investment in productive goods and the funding of enterprises are still rare. On the other hand, migration is dangerous and risky. Many migrants have no official registration and are vulnerable to arbitrary action by law enforcement bodies. Moreover, the permanent out-migration of a qualified workforce leads to a 'brain drain' which can worsen the prospects for socio-economic development in the long term. The separation of families, its social and psychological consequences, and the reduction of the labour force in the village itself are other aspects that need to be mentioned. Furthermore, the frequent alternation between home and destination regions of the labour migrants from Kyrgyzstan leads to the construction of social fields which transcend national states and consequently result in the evolution of multilocal spheres; one part of the population lives elsewhere but is still connected with the home region in economic, social, political and cultural terms.

Labour migration to Russia from the new republics of Central Asia will continue and probably increase as long as the economic problems especially in Kyrgyzstan, Tajikistan and Uzbekistan are not solved and Russia's economic success continues. If international labour migration is understood as a means to realize chances of participation in the globalization processes, then migrants succeed to different extents depending on their individual abilities and on political, legal, economic and social circumstances. But it becomes obvious that at the national level the economic dependency of Kyrgyzstan on the Soviet centre is being superseded by the need of regular flows of remittances from labour migrants abroad.

\section{Notes}

1. For a discussion of clan structures in Central Asia, see Collins (2006).

2. In contrast, the structural unemployment in the rural areas and the economic gap between rural and urban areas is stressed by Patnaik (1995).

3. Oral information from the State Committee for Migration of the Kyrgyz Republic in Moscow.

4. The estimates of illegal migrants in Russia differ between 1.5 million and more than 6 million (Ivakhniouk 2004).

5. The standardized questionnaire comprised 30 questions, and the questioning took approximately 30 to 50 minutes. The main topics of the survey were direction, duration and reasons for migration, biographical, educational and economic background of the migrants and the households, networks, situation in the target region (employment, living conditions and salary), expectations and reality of migration, relations between migrants and home, and finally consequences of migration.

6. Information provided by the local administrations.

7. Information provided by the local administrations.

8. Information provided by the local administrations. 
9. Such an explanation follows classical migration research theories, in which migration is seen as helping to equalize differences between regions in the supply of and demand for labour, and will lead to optimal resource allocation (Todaro 1969, Borjas 1989, Stark 1991, Massey et al. 1993, Taylor et al. 1996).

10. The theory of the dual labour market offers explanations why labour migrants are willing to accept bad working conditions, low wages and low prestige jobs which are avoided by labourers of the destination country (Piore 1979).

11. On the other hand, according to local Kyrgyz authorities, between 4000 and 5000 Uzbek citizens work mainly on a seasonal basis in Kyrgyzstan, such as cotton pickers in the Jalalabad region (Elebaeva 2004, p. 80). The majority work illegally without labour contracts and are not covered by social and other benefits. Their daily wages amount to approximately US\$1; in many cases they are not paid at all and are treated abominably.

12. Shuttle traders selling Chinese goods in Russian markets can earn up to US\$1000 a month, hired sellers on average US\$200-250, unskilled workers in construction up to US\$100, skilled workers up to US\$400, which is much lower than the average wages of legally employed workers (Elebaeva 2004, p. 81).

13. Regarding problems and conditions of returned labour migrants in Kyrgyzstan, see Turgunbayev et al. (2007). 14. These facts perfectly fit into the world system theory that focuses on the structure of the world market and sees migration as a consequence of economic globalization processes; it further postulates that borders and protection against illegal immigrants have deliberate holes, since illegal immigrants are necessary as a cheap labour force (Hopkins and Wallerstein1982).

15. The government of the Kyrgyz Republic and competent organizations undertake measures intended to improve the conditions of labour migrants from Kyrgyzstan in Russia and Kazakhstan. Consulates General were opened in Russian cities to monitor the residence and work situation of Kyrgyz labour migrants. However, most labour migrants are not informed about their rights (Dmitrienko and Kusnecova 2000).

\section{References}

Abazov, R., 1999. Economic migration in post-soviet Central Asia: the case of Kyrgyzstan. PostCommunist Economies, 11 (2), 237-252.

Abazov, R., 2000. Migration of population, the labour market and economic changes in Kirghizstan. In: K. Hisao, O. Chika and J.S. Schoeberlein, eds. Migration in Central Asia: its history and current problems. Osaka: The Japan Center for Area Studies, 209-235.

Akademiia NaukKirgizskoi SSR, 1982. Kirgizskaia Sovetskaia Socsialisticheskaia Respublikaenciklopediia. Frunze: Glavnaia Redaktsiia Kirgizskoi Sovetskoi Enciklopedii.

Bailey, A.J., 2001. Turning transnational: notes on the theorisation of international migration. International Journal of Population Geography, 7 (6), 413-428.

Becker, C.M. et al., 2005. The migration response to economic shock: lessons from Kazakhstan. Journal of Comparative Economics, 33 (1), 107-132.

Bichsel, C., Hostettler, S. and Strasser, B., 2005. Should I buy a cow or a TV? Reflections on the conceptual framework of the NCCR North-South based on a comparative study of international labour migration in Mexico, India and Kyrgyzstan. Berne: National Centre for Competence in Research North-South, Joint Working Paper.

Bloch, P.C. and Rasmussen, K., 1998. Land reform in Kyrgyzstan. In: S.K. Wegren, ed. Land reform in the former Soviet Union and Eastern Europe. London: Routledge, 111-135.

Borjas, G.J., 1989. Economic theory and international migration. International Migration Review, 23 (3), 457-485.

Borovik, M. and Chemberko, L., 1998. A multidimensional approach to modern migration processes on the former Soviet territory. Beitra"ge zur Regionalen Geographie Europas, 47, 136-141.

Boyd, M., 1989. Family and personal networks in international migration: recent development and new agendas. International Migration Review, 23 (3), 638-670.

Collins, K., 2006. Clan politics and regime transition in Central Asia. Cambridge: Cambridge University Press. 
Dmitrienko, V.N. and Kusnecova, L.P., 2000. Problemy ocenki i regulirovania processov trudovoi migracii v Kyrgyzskoi Respublike. In:G.V.Kumskov, ed. Migracionnye processy v Kyrgyzstane na sovremennom etape: vneshniaia migracia Russkoiazychnogo naseleniaKyrgyzstana, problemy i posledstvia.Bishkek: Kyrgyz-Russian Slavonic University.

Elebaeva, A., 2002. Migration in post-soviet Kyrgyzstan: nature, trends and types. Central Asia and the Caucasus, 18 (6), 151-157.

Elebaeva, A., 2004. Labor migration in Kyrgyzstan. Central Asia and the Caucasus, 27 (3), 78-86.

Ergeshbaev, U., 2006. External labor migration of Kyrgyzstan's indigenous population and its socioeconomic consequences. Central Eurasian Studies Review, 5 (2), 40-43.

Fawcett, J.T., 1989. Networks, linkages, and migration systems. International Migration Review, 23 (3), 671-680.

Ginzburg, A. et al., 1993. Russkiye v novom zarubezh'ye: Srednaya Aziya. Moscow: Institut Etnologii I Antropologii.

Glick Schiller, N., Basch, L. and Blanc-Szanton, C., 1992. Towards a transnational perspective on migration: race, class, ethnicity, and nationalism reconsidered. New York: New York Academy of Sciences.

Hopkins, T.K. and Wallerstein, I., 1982. World-systems analysis: theory and methodology. Beverly Hills: Sage.

International Organisation of Migration, 2001. Vnutrenniaia migracia v Kyrgyzskoi Respublike. Bishkek: International Organisation of Migration.

Islamov, B., 2000. Migration of population in independent states of Central Asia. In: K. Hisao, O. Chika and J.S. Schoeberlein, eds. Migration in Central Asia: its history and current problems. Osaka: The Japan Center for Area Studies, 179-197.

Ivakhniouk, I., 2004. Illegal migration: Russia. European Security, 13 (1), 35-53.

Kaiser, R.J., 1995. Nationalizing the work force: ethnic restratification in the newly independent states. Post-Soviet Geography, 36, 87-111.

Katsunori, N., 2000. Russian colonization in Central Asia: a case of Semirechye, 1867-1922. In: K. Hisao, 0. Chika and J.S. Schoeberlein, eds. Migration in Central Asia: its history and current problems. Osaka: The Japan Center for Area Studies, 65-84.

Korobkov, A.V., 2007. Migration trends in Central Eurasia: politics versus economics. Communist and Post-Communist Studies, 40 (2), 169-189. Central Asian Survey 125 Downloaded By: [Freie Universitat Berlin] At: 07:56 29 September 2008

Kumskov, G.V., ed., 2000. Migracionnye processy v Kyrgyzstane na sovremennom etape: vneshniaia migracia Russkoiasychnogo naselenia Kyrgystana, problemy i posledstvia. Bishkek: KyrgyzRussian Slavonic University.

Massey, D. et al., 1993. Theories of international migration: a review and appraisal. Population and Development Review, 19, 431-466.

Matthews, M., 1993. The passport society: controlling movement in Russia and the USSR. Boulder: Westview Press.

National Statistical Committee of the Kyrgyz Republic, 2000. Main results of the first national population census of the Kyrgyz Republic of 1999. Bishkek: National Statistical Committee of the Kyrgyz Republic.

National Statistical Committee of the Kyrgyz Republic, 2002. Migration of the population of Kyrgyzstan. Results of the first national population census of the Kyrgyz Republic of 1999 in tables. Bishkek: National Statistical Committee of the Kyrgyz Republic. 
National Statistical Committee of the Kyrgyz Republic, 2004. Kyrgyzstan v cifrax. Bishkek: National Statistical Committee of the Kyrgyz Republic.

Patnaik, A., 1995. Agriculture and rural out-migration in Central Asia, 1960-91. Europe-Asia Studies, 47 (1), 147-169.

Piore, M.J., 1979. Birds of passage: migrant labor in industrial societies. London: Cambridge University Press.

Pole, J.P. and Filatotchev, I.V., 1992. Some observations on migration within and from the former USSR in the 1990s. Post-Soviet Geography, 33 (7), 432-453.

Polian, P., 2004. Against their will: the history and geography of forced migrations in the USSR. Budapest: Central European University Press.

Pries, L., ed., 2001. New transnational social spaces: international migration and transnational companies in the early twenty-first century. London: Routledge.

Radnitz, S., 2006. Weighing the political and economic motivations for migration in post-soviet space: the case of Uzbekistan. Europe-Asia Studies, 58 (5), 653-677.

Rowland, R.H., 1988. Union republic migration trends in the USSR during the 1980s. Soviet Geography, 29 (9), 809-829.

Rybakovskiy, L.L. and Tarasova, N.V., 1991. Contemporary problems of migration of the population of the USSR. Soviet Geography, 32 (7), 458-473.

Sarygulov, B.A., 2005. Sovremennaia situacia i aktual'nye problemy trudovoi migracii v Kyrgyzskoi Respublike i al'ternativy perspektiv ee regulirovania. Bishkek: Department of Migration Service, Ministry of Foreign Affairs of the Kyrgyz Republic.

Schmidt, M., 2005. Utilisation and management changes in South Kyrgyzstan's mountain forests. Journal of Mountain Sciences, 2 (2), 91-104.

Schoeberlein, J.S., 2000. Shifting ground: how the Soviet regime used resettlement to transform Central Asian society and the consequences of this policy today. In: K. Hisao, O. Chika and J.S. Schoeberlein, eds. Migration in Central Asia: its history and current problems. Osaka: The Japan Center for Area Studies, 41-64.

Schwarz, T., 2000. Arbeitsmigration in den Nachfolgestaaten der Sowjetunion: Die Eingliederung der GUS in das globale Wanderungssystem. In: H.H. Blotevogel, J. Ossenbrügge and G. Wood, eds. Lokal verankert-weltweit vernetzt, Tagungsbericht und wissenschaftliche Abhandlungen, 52. Deutscher Geographentag Hamburg. Stuttgart: Franz Steiner, 309-313.

Seddon, D., 2004. South Asian remittances: implications for development. Contemporary South Asia, 13 (4), 403-420.

Stadelbauer, J., 2003. Migration in den Staaten der GUS. Geographische Rundschau, 55 (6), 36-44.

Stark, O., 1991. The migration of labor. Oxford: Blackwell.

Sulaimanova, S., 2005. Irregular labor migration from Central Asia to the United States. Central Eurasian Studies Review, 4 (1), 9-12.

Sutherland, D. and Hanson, P., 2000. Demographic response to regional economic change: interregional migration. In: P. Hanson and M. Bradshaw, eds. Regional economic change in Russia. Cheltenham: Edward Elgar, 76-96.

Taylor, J.E. et al., 1996. International migration and community development. Population Index, 62 (3), 397-418.

Titma, M. and Tuma, N.B., 1992. Migration in the former Soviet Union. Berichte des Bundesinstituts für ostwissenschaftliche Studien, 22. 126 M. Schmidt and L. Sagynbekova Downloaded By: [Freie Universitat Berlin] At: 07:56 29 September 2008 
Todaro, M.P., 1969. A model of labor migration and urban unemployment in less developed countries. The American Economic Review, 59 (1), 138-148.

Toralieva, G., 2006. Labor migration: a lost population? Articles Analyzing Politics in Kyrgyzstan, Institute for Public Policy. Available from: http://ipp.kg/en/analysis/202-6-06-2006 [Accessed 20 July 2006].

Turgunbayev, T.S. et al., 2007. Conditions and state of social rehabilitation of labor migrants-citizens of the Kyrgyz Republic following their return to homeland, analytical report. Bishkek: Representative Office of Rast Foundation in Kyrgyzstan, Social Research Center of American University in Central Asia.

United Nations in the Kyrgyz Republic, 2001. Kyrgyzstan: common country assessment. Bishkek: The United Nations System in the Kyrgyz Republic.

United Nations in the Kyrgyz Republic, 2003. Kyrgyz Republic: common country assessment. Bishkek: The United Nations System in the Kyrgyz Republic.

Wegren, S. and Drury, C., 2001. Patterns of internal migration during the Russian transition. Journal of Communist Studies and Transition Politics, 17 (4), 15-42.

Wilpert, C., 1992. The use of social networks in Turkish migration to Germany. In: M.M. Kritz, L.L. Lim and H. Zlotnik, eds. International migration systems: a global approach. Oxford: Clarendon Press, 177-189.

Yessenova, S., 2005. 'Routes and roots' of Kazakh identity: urban migration in postsocialist Kazakhstan. The Russian Review, 64 (4), 661-679.

Zaslavskaya, T.I. and Korel, L.V., 1984. Rural-urban migration in the USSR: problems and prospects. Sociologia Ruralis, 24 (3-4), 229-241.

Zayonchkovskaja, Z. and Polian, P., 1998. Migration in Russia and the former Soviet Union. Beitra"ge zur Regionalen Geographie Europas, 47, 159-176. 